\title{
IfIISGUCDERGI.ORG
}

"IȘ, GÜç̣" ENDÜSTRi iLIȘKiLERi VE INSAN KAYNAKLARI DERGISi

"IS, GUC" INDUSTRIAL RELATIONS AND HUMAN RESOURCES JOURNAL

\section{What Would Parsons Say About Mobbing?}

\section{Dr. Umut Omay}

Istanbul University, Faculty of Economics

umutomay@hotmail.com

Ekim/October 2009, Cilt/Vol: 11, Sayı/Num: 5, Page: 67-78

ISSN: 1303-2860, DOI: 10.4026/1303-2860.2009.0126.x

Makalenin on-line kopyasına erişmek için:

http://www.isgucdergi.org/?p=makale\&id=398\&cilt=11\&sayi=5\&yil=2009

To reach the on-line copy of article:

http://www.isguc.org/?p=article\&id=398\&vol=11\&num=5\&year=2009

Makale İçin İletişim/Correspondence to:

Yazarların e-posta adresleri verilmiştir. Writers e-mail was given for contact. 
(C) 2000- 2009

"İşGüç̧" Endüstri İlişkileri ve İnsan Kaynakları Dergisi

"İşGǚç" Industrial Relations and Human Resources Journal

Ekim/October 2009, Cilt/Vol: 11, Say1/Num: 5

ISSN: 1303-2860, DOI: 10.4026/1303-2860.2009.0126.x

Editör/Editor-in-Chief

Aşkın Keser (Kocaeli University)

Editör Yardımcıları/Co-Editors

K.Ahmet Sevimli (Uludağ University)

Gözde Yilmaz (Kocaeli University)

Uygulama/Design

Yusuf Budak (Kocaeli Universtiy)

\author{
Yayin Kurulu / Publishing Committee \\ Dr.Zerrin Firat (Uludăg University) \\ Doç.Dr.Aşkın Keser (Kocaeli University) \\ Prof.Dr.Ahmet Selamoğlu (Kocaeli University) \\ Yrd.Doç.Dr.Ahmet Sevimli (Uludağ University) \\ Yrd.Doç.Dr.Abdulkadir Şenkal (Kocaeli University) \\ Yrd.Doç.Dr.Gözde Yilmaz (Kocaeli University) \\ Dr.Memet Zencirkıran (Uludağ University)
}

Uluslararası Danışma Kurulu / International Advisory Board

Prof.Dr.Ronald Burke (York University-Kanada)

Assoc.Prof.Dr.Glenn Dawes (James Cook University-Avustralya)

Prof.Dr.Jan Dul (Erasmus University-Hollanda)

Prof.Dr.Alev Efendioğlu (University of San Francisco-ABD)

Prof.Dr.Adrian Furnham (University College London-İngiltere)

Prof.Dr.Alan Geare (University of Otago- Yeni Zellanda)

Prof.Dr. Ricky Griffin (TAMU-Texas AEM University-ABD)

Assoc. Prof. Dr. Diana Lipinskiene (Kaunos University-Litvanya)

Prof.Dr.George Manning (Northern Kentucky University-ABD)

Prof. Dr. William (L.) Murray (University of San Francisco-ABD)

Prof.Dr.Mustafa Özbilgin (University of East Anglia-UK)

Assoc. Prof. Owen Stanley (James Cook University-Avustralya)

Prof.Dr.Işık Urla Zeytinoğlu (McMaster University-Kanada)

Danışma Kurulu / National Advisory Board

Prof.Dr.Yusuf Alper (Uludağ University)

Prof.Dr.Veysel Bozkurt (Uludağ University)

Prof.Dr.Toker Dereli (Işık University)

Prof.Dr.Nihat Erdoğmuş (Kocaeli University)

Prof.Dr.Ahmet Makal (Ankara University)

Prof.Dr.Ahmet Selamoğlu (Kocaeli University)

Prof.Dr.Nadir Suğur (Anadolu University)

Prof.Dr.Nursel Telman (Maltepe University)

Prof.Dr.Cavide Uyargil (İstanbul University)

Prof.Dr.Engin Yildırım (Sakarya University)

Doç.Dr.Arzu Wasti (Sabancı University)

Dergide yayınlanan yazılardaki görüşler ve bu konudaki sorumluluk yazarlarma aittir.

Yayınlanan eserlerde yer alan tüm içerik kaynak gösterilmeden kullanılamaz.

All the opinions written in articles are under responsibilities of the outhors.

None of the contents published can't be used without being cited. 


\title{
What Would Parsons Say About Mobbing?
}

\author{
Dr. Umut Omay \\ Istanbul University, Faculty of Economics \\ umutomay@hotmail.com
}

\begin{abstract}
:
In the recent years Mobbing has been a popular subject among the Work Psychology studies. Mobbing can simply be defined as a malicious attempt to force a person by another person or a group systematically in order to erode the said person's thrust, willingness and morale. The popularity of mobbing as a research subject has been parallel to the rise of the of the Human Resource Management and Organizational Behavior fields. Thus, there have been many research in this field so far. But the popularity of the subject "Mobbing" must be criticised. Because, in the working life of today, any kind of conflict has begun to be labeled as mobbing while some of them actually cannot be defined as mobbing. After studying carefully and comparatively the given data and the results of the related surveys by a sociological view, it is possible to claim that there may have been simpler and more different explanations other than mobbing for the most of the mobbing claims. The purpose of this paper is to show that "Mobbing" is a questionable subject which needs to be redefined. The methodology of this paper is a fictional research, depending on comparative analysis on some of the results of the related surveys by using Parsons' sociological approach. Parsons Methodology may seem as an inappropriate tool to analyze the concept of mobbing because it is the most contrary approach for analyzing the subject and has the potential to justify mobbing. But that potential may help for the researchers to find out whether all of the mobbing claims are reflecting the true mobbing events or not.
\end{abstract}

Keywords: Mobbing, Social Action, Social System, A.G.I.L., Pattern Variables, Parsons. 


\section{INTRODUCTION}

Mobbing has been an emerging subject among the Human Resource management and Organizational Behaviour fields. Thus, there have been lots of studies and surveys on the subject. But, a common belief on mobbing has been, it is the subject of psychological approach. In other words, mobbing has been a subject of research only in the psychological perspective. As it is the result of a group of persons' behaviour, mobbing should also be the subject of sociological approach. After studying carefully and comparatively on the given data and results of the related surveys by a sociological view, it is also possible to claim that mobbing is not only the subject of psychological approach but also it can be the subject of sociological approach.

\section{A BRIEF DEFINITION OF MOBBING}

Mobbing is a common word to highlight the malicious behaviour against a person in a group. Human Resource Management and Organizational Behaviour fields have taken interest mostly on mobbing which is defined as "workplace mobbing". In this study, mobbing is considered as the "workplace mobbing". According to Davenport, mobbing may be defined as "a malicious attempt to force a person out of the workplace through unjustified accusations, humiliation, general harassment, emotional abuse, and / or terror." (Yücetürk and Öke, 2005: 61). According to Leymann, one of the leading figures in the mobbing studies, mobbing is defined such as follows:

"Psychical terror or mobbing in working life means hostile and unethical communication which is directed in a systematic way by one or a number of persons mainly toward one individual. There are also cases where such mobbing is mutual until one of the participants becomes the underdog. These actions take place often (almost every day) and over a long period (at least for six months) and, because of this frequency and duration, result in considerable psychic, psychosomatic and social misery. This definition eliminates temporary conflicts and focuses on the transition zone where the psychosocial situation starts to result in psychiatric and/or psychosomatic pathological states." (Leymann, 1990: 120).

Being a popular subject, mobbing has not been the sole term in use: for example "incivility (Andersson \&Pearson, 1999), ... , bullying (Einarsen\&Skogstad, 1996; Namie\&Namie, 2000), harassment (Björkvistet al., 1994); petty tyranny (Ashforth, 1994), abusive disrespect (Hornstein, 1996), interactional injustice (Harlos \& Pinder, 2000), emotional abuse (Keashly, 1998), mistreatment (Folger, 1993; Price Spratlen, 1995), abuse (Bassman, 1992), aggression (Neuman\&Baron, 1998), deviance (Robinson \& Bennett, 1995), and victimization (Swedish National Board of Occupational Safety and Health, 1993)" (Blase and Blase, 2002: 674). As seen in the given examples, mobbing is not the unique term while there are many others. The reason of being defined in many terms, is just about the assumes about its content. As indicated in a research report by Ontario Public Service Employees Union, mobbing could be worse than bullying.(OPSEU, 2007: 3) ${ }^{1}$

The target can be victimized by verbal or written threats, implications, gossip, harassment, humiliation and so on. The target's dignity and professionals competence is under assault therefore the target's communication with his/her friends is encumbered and given a new work place. S/He has also limited duties. When $\mathrm{s} /$ he reacts, $\mathrm{s} /$ he is accused of being the hard one. Finally, the target can suffer from psychological diseases and is forced to quit the job. But s/he has chosen to quit the job of his/her own choice the others would say. Bullies mostly, hypoc-

1 In this article, mobbing is held as to define all of the term given above. 
rite, jealous people who are seeking to humiliate others to mask their incompetency and fear. By making fun of the target, they try to overcome their incompetency.

The targets are rather competent, creative, moral, plausible, devoted people who are deeply affected when they lose their job (Tinaz, 2006: 11-13 ; Ok, 2008).

As indicated above, mobbing is a psychological and emotional fact. The mobbing process is shown in the figure 1 :

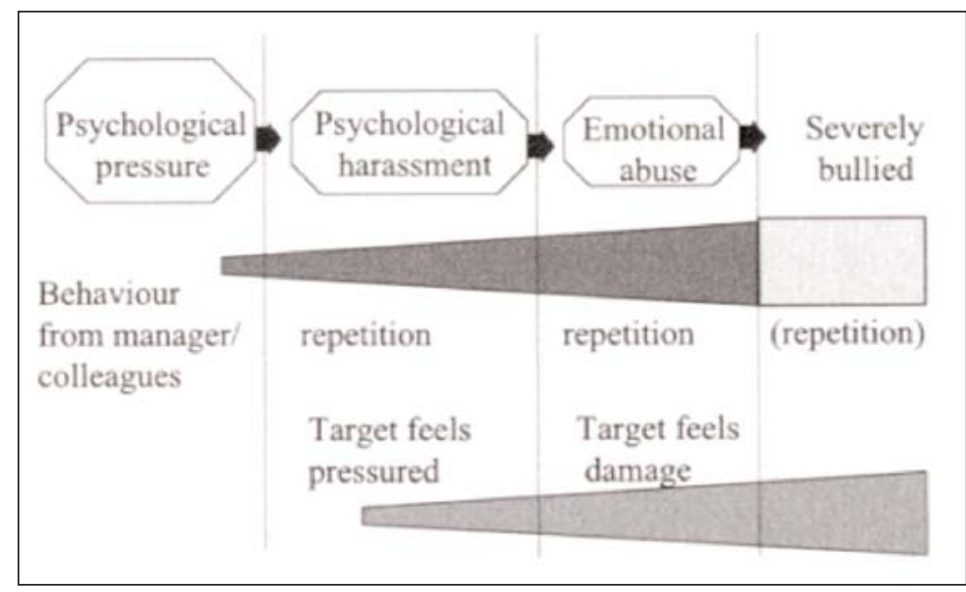

Figure 1: A schema of bullying [mobbing] at work.

Source: (Rayner et al., 2002: 10).

As it is seen in the Figure 1, mobbing process is considered to have four types/stages. Those can be a unique level as well as stage followed each other starting from psychological pressure. On the psychological pressure level, target (victim) feels a little bit pressured. But if the psychological pressure turns into psychological harassment level, target (victim) feels the pressure much more evidently. The third level is called emotional abuse in which target (victim) feels damage and in the last level mobbing is fully forced to the target (victim). Literally, "mobbing has been considered a severe social stressor (Zapf, 1999), a traumatic vital event (Wilson, 1991), a silent epidemic that causes job dissatisfaction, psychological distress, and psychosomatic and physical problems." (Pedro et al., 2008: 220)

According to Leymann, mobbing should be considered as a manipulation process which is about:

"1. The victim's reputation (rumor mongering, slandering, holding up to ridicule).

2. Communication toward the victim (the victim is not allowed to express $\mathrm{him} /$ herself, no one is speaking to him or her, continual loud-voiced criticism and meaningful glances).

3. The social circumstances (the victim is isolated, sent to Coventry).

4. The nature of or the possibility of performing in his/her work (no work given, humiliating or meaningless work tasks).

5. Violence and threats of violence."(Leymann, 1990: 121)

Another important point is about the background of mobbing. As seen in Figure 2, the mobbing process is affected basically by the "cultural and socio-economical factors". This is an important point for the said factors' effecting the mobbing process as a whole. .

It is evident that mobbing can be assumed as a socio-cultural and economic result. But the great question still remains unanswered: What causes mobbing? There should be doubts that mobbing should not be considered as a sole subject of psychology but also it should be considered as a subject of sociology. As it is seen in Figure 2, mobbing process may be supposed as a psychological phenomenon in its-self but it can also be assumed as the subject of sociology in a common sense. Thus, with a sociological view, mobbing can be considered as a social action in a social system.

\section{TALCOTT PARSONS AND HIS STUDIES}

Talcott Parsons (1902 - 1979) has been a leading figure in sociology, and mostly in the American Sociology. Parsons was famous mostly with his two major works which 


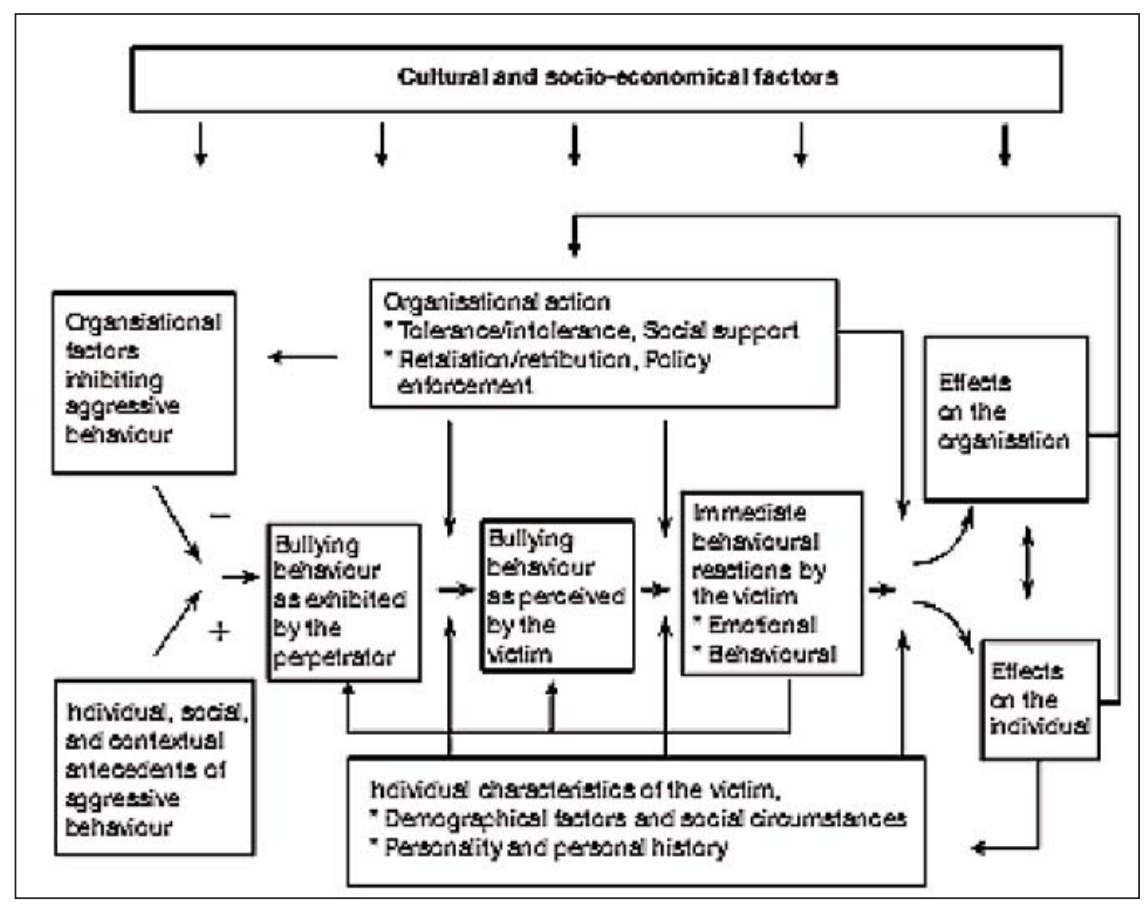

Figure 2: The interrelation elements of Mobbing.

Source: (Einarsen et. al., 2003: 23).

were "The Structure of Social Action" and "The Social System".

Parsons derived system theory from cybernetics which is a study field of biology (Edgar, 2006: 156). Parsons especially deeply affected from Durkheim's and Weber's cultural sociology thesis and emphasized the importance of systematical theorizing. In order to understand contemporary culture theories Parsons' studies should be deeply analyzed. Parsons main objective was to synthesize the general objectives in sociology from Durkheim, Malinowski, Freud and Weber so that he could explain the societal norms and individual responses(Slattery, 2007: 375-376).

Parsons' remarkable works were on defining and explaining "action" as well as defining and explaining "social system". According to Parsons, action should not be understood as an isolated subject, but "as a process in time, or as a system". (Applerouth and Edles, 2008: 351). "...more generally, he saw social action composed of four basic elements that distinguish it from isolated, individual behavior:

1. it is oriented toward attainment of ends and goals,

2. it takes place in situations, consisting the physical and social objects to which the actor relates,

3 . it is normatively regulated (i.e., regulated by norms that guide the orientation of action),

4. it involves expenditure of effort or energy" (Applerouth and Edles, 2008: 352)

Another important point is, Parsons' differentiation of symbols from norms. He argued that symbols were the attribute meaning to situations given by the actors ${ }^{2}$ while norms were the rules for behavior.(Applerouth and Edles, 2008: 352) By doing so, Parsons aimed to highlight the internal and external variables of the action.

According to Parsons the core of the system depends on interaction between people. But the most important units in a society are roles (Smith, 2005: 45-46). The contents of the roles are controversial. Because Parsons explains the roles with expectation hypothesis (Smith, 2005: 46).

\footnotetext{
2 Parsons attaches importance to role which comprises the expectancies from the person. The most known example is the "sick role". "These relationships are socially structured in a uniform way for a group of individuals, it does not follow that the ways in which these uniform "roles" are structured are constitutive of each of the different personalities in the same way. Each is integrated into a different personality system, and therefore does not in a precise sense "mean the same thing" to any two of them. The relation of personality to a uniform role structure is one of interdependence and interpenetration but not one of "inclusion" where the properties of the personality system are constituted by the roles of which it is allegedly "made up." (Parsons, 1991: 10).
} 
Parsons improved the social action theory later with the collaboration of Shils. "In Toward a General Theory of Action ... Parsons and Shils develop a set of concepts called the pattern variables." (Applerouth and Edles, 2008: 355). Those are: affectivity v. affectiveneutrality, self v. collectivity orientation, universalism $\mathrm{v}$. particularism, ascription $\mathrm{v}$. achievement, specificity v. diffuseness. (Turner, 1999: 173). The pattern variables can be explained as follows (Applerouth and Edles, 2008: 356):

Affectivity v. Affective-Neutrality: Affectivity describes the gratified emotional impulses while affective-neutrality describes the inhibited emotional impulses.

Self-orientation v. Collectivity-orientation: Self-orientation describes the action of an actor's improving his own interests, goals or needs while collectivity-orientation describes the action for the betterment of a group of people.

Universalism v. Particularism: Universalism describes the action's being based on "general standards" or universal laws and moral rules while particularism describes the action's being based on the priority and attachment actors place on relationships and situations.

Ascription v. Achievement: Ascription describes the action's being based on given attributes such as race, sex and age while achievement describes the action on performance basis.

Specificity v. Diffuseness: Specificity describes the action being based on specific criteria or roles while diffuseness describes the action's open guidelines.

Parsons purpose was to explain and to understand the relationship between the social structures and social organizations. He argued that social structures condition the social actions. He used the pattern of variables to show the different types of societies have different institutional relationships such as in pre-modern societies where there are different value orientations, work is intermingled with family life, and there are less cultural institutions. On the other hand, in modern societies there are different valueorientations because what you experience socially is closely related with your behavior. Therefore, Parsons argued that in different socially structured societies one can experience different patterns of behavior. He termed them pattern variables because they are patterns of general values and they vary from one society to another according to the complexity of the institutional relationships in the society. He developed two types of pattern variables for pre-modern and modern societies Type A and type B respectively (http:/ / www.sociology.org.uk)

In pre-modern societies, there are five pattern variables. They are ascription, diffuseness, particularism, affectivity, and collective orientation. Ascription refers to status. Social status is given to the member by others where as individual status is closely related to which family you are born into. Diffuseness refers to the large range of needs in pre-modern societies like in the mother and child relationship which satisfies a large range of psychological and sociological needs. Particularism is how people act towards particular people due to the nature of their relationship You can trust to your family but not a stranger. Affectivity shows that inter-personal relationships are based on trust, love, personal involvement etc. rather than interests. In collective-orientation people value the interests of the social groups they belong more than their personal interests. (http:/ / www.sociology.org.uk)

In modern societies, there are different value-orientations contrasted to premodern societies. They are; achievement which means that social status is achieved by your personal merits; specificity which shows the wideness of relationships people enter into everyday; universalism, refers to the universal values and norms that one has to obey in the society, instrumental demonstrates the web of relationships based on the personal interests of people and lastly, selforientation indicates the self-interests people pursue above their groups interests. (http://www.sociology.org.uk) 
Parsons argues that there are four "functional imperatives" needed to be handled by the social system, or group or individual to survive. (Appelrouth and Edles, 2008: 360). Those are defined by Parsons as, Adaptation, Goal attainment, Integration, Latency. Simply those are known as "AGIL" or "GAIL" systems which are the main subsystems of the social system. (Turner, 1991: $\mathrm{xviii})$. The 4 th principle latency corresponds to the cultural sub-system. Therefore; culture should be accepted as another system. We can explain the AGIL model (Slattery, 2007: 376; Smith, 2005: 48-49; Edgar, 2006: 156):

1. (A) stands for Adaptation : Every system and society should provide the basic needs (food, shelter, clothing) and Parsons attaches importance to economy in this respect.

2. (G) stands for Goal attainment: to define an objective for goal attainment and leadership and making decisions is important.

3. (I) stands for integration: to avoid conflicts and disintegration in the society. So, the society (or the social system) shall keep itself from the risk of societal collapse. Parsons explained the term "integration" with norms (religion), communication (media) and social control (law, courts, prisons, etc.).

4. (L) stands for Latency which is latent pattern maintenance and tension management. The members in the society are continually changing by deaths and births. So, latency is about how the society survives. In order to achieve this, socialization and solidarity are necessary. Social intuitions like church, school, family are necessary to strengthen the socialization process. That is how individuals are adapted to their social roles. Parsons defines the said subsystems such as shown in the Figure 3:

Parsons tried to lessen the relations among the social system and sub-system to the last smallest units which are also systems at their own (Edgar, 2006: 156). The system, designed by Parsons, may be summarized as the Matrushka Dolls (Smith, 2005: 49).

In short, Parsons was on the very importance of the surveillance of the social system. And the surveillance of the social system depends on both the social action theory and AGIL system.

\subsection{MAIN CRITISIMS ON PARSONS SOCIOLOGY}

The main criticisms on Parsons Sociology are as follows; Parsons approach is too dependent on determinism principle. Because it defines people like small cogs in a social machine and also puppets without free-will. Social consensus and order is too much emphasized and he does not consider the effect of power. That's why it is not adequate to explain social conflicts and therefore accepts the society as homogeneous. He does not take struggle and reconciliation into consideration he takes culture as a something that reinforces the systems continuity. That's why Parsons Model is considered as abstraction. He denies cultures creativity and agency. Some of the criticisms are directed to inculturality of Parsons Analysis. They say he perceives culture and universal norms incom-

\begin{tabular}{|c|c|}
$\begin{array}{c}\text { ADAPTATION } \\
\text { (Refers to material environment which is about } \\
\text { resources. This is economic system (resources) for the } \\
\text { society). }\end{array}$ & $\begin{array}{c}\text { GOAL ATTAINMENT } \\
\text { (Refers to ability of individual or group to identify and } \\
\text { pursue goals. This is polity (goals) for the society). }\end{array}$ \\
INTEGRATION & $\begin{array}{c}\text { LATENCY (LATENT PATTERN MAINTENANCE) } \\
\text { (Cultural system of general } \\
\text { (The normative problem of motivation to fulfil } \\
\text { positions in the social system. This is cultural system } \\
\text { (values) for the society). }\end{array}$ \\
$\begin{array}{c}\text { values which is concerned with law and social control. } \\
\text { This is social system (norms, interaction) for the } \\
\text { society). }\end{array}$
\end{tabular}

Figure 3: AGIL system.

Source: Prepared by using (Appelrouth and Edles, 2008: 360- 361) and (Turner, 1991: xviii). 
plete. He is conservative and defends societal order. He is too much on behalf of American values (Slattery, 2005; 379-380; Edgar, 2006; 156157; Smith, 2005; 54-55). As a matter of fact Parsons defends the American society in his own words: "American society institutionalizes the state of freedom than any society does."(Smith, 2005: 53).

But criticism towards Parsons began to diminish from 1980s onwards. The new functionalism accepts that there is some point in criticizing Parsons but also states that his opponents are not deep enough to criticize him.

\section{WHAT WOULD PARSONS SAY ABOUT MOBBING?}

What would Parsons say about mobbing is a fictional task. I underwent this task because what has been said of mobbing remains somewhat missing due to the lack of the sociological perspective. It should be noted that "Mobbing" is a fact but I am really very suspicious about most of the current mobbing claims being really the result of mobbing. Human behavior is closely linked with the society one lives into argues Parsons. I therefore, think that mobbing is a kind of utilization mechanism or the social system. In modern societies people enter into different kinds of relationships everyday for their sole interests. And working life is such a social system. According to Parsons, every social system depends on social actions. Mobbing in the work place, is one of the most popular research subjects. Mobbing, in essence is a social action at the same time it refers to a social system, so, it should be analyzed by using Parsons Methodology.

Nevertheless, mobbing is rather referred as a psychological phenomenon up to now. Moreover, the research data shows inconsistency; the results of the related surveys seem a little bit problematic. This is because, especially the demographical results seem to be somewhat controversial. For example, there are some contrary findings about the age pattern: "In literature; some researchers found no significant difference between young and old employees in frequency of being bullied (Quine 2002). Ho- wever Einarsen and Rankes (1997), Hoel and Cooper (2000) and Quine (1999) paralelly discovered that employees at young ages were at more risk of being a victim. Contrastly to these findings, it was reported at Einarsen and Skogstad's (1996) study that older employees were exposed to [...] bullying more that the younger employees." (Gülen, 2008: 156) Again, in an other study the victims were found older than 35 years of age ( Palaz et al., 2008: 52) and in an other it argued that the victims are under 25 and above 55 years of age (See Di Pasquale, 2002).

So, it is possible to claim that there are no distinctive personality traits between the mobbing targets; anybody can be a mobbing target. In surveys, the common characteristics of mobbing targets are the loyalty and identification they feel for the job. According to Davenport and et al. especially creative people have the most possibility to be the mobbing targets because of their creating new ideas which disturb the others as a result of considered as a threat to their superiors. (Paksoy, 2007: 25) ${ }^{3}$ This explanation should not be considered as certain and common but an inspiring one.

How Parsons Sociology can be a productive resource in mobbing studies showed itself in a recent study. In a mobbing interview in the study the victim defined herself as a scapegoat: "They scapegoated! A scapegoat is often a way of resolving a situation, they take the easy way out which is to get rid of that one person while they retain the ones who are creating the difficulty because it's easier to eliminate the one..." (Shallcross et al., 2008: 63). At this point, it brings Parsons social action theory and the social system into mind.

According to Parsons and Shils, "a particular important feature of all systems is the inherent limitation on the compatibility of certain parts or events within the same system. This is indeed simply another way of saying that the relations within the system are determinate and just anything can happen." (Appelrouth and Edles, 2008: 348). So, Parsons would say that mobbing is related with the compatibility and determinity of the social system. In this respect, 
this social system is the workplace.

Due to a more common idea, young people are more subjected to mobbing. For example, according to a recent study (see Kaymakçı, 2008: $607)$, the victims, in Turkey, are mostly (59,1\%) 25 or younger than 25 years old. It is not suprising that in Turkey, there is a common notion that young people are rather considered as immature and naive by their elders or superiors. As Rayner states, it is just the function of position (Rayner et al., $2002: 69-70$ ). The position gives the elder the right to bully the young and the immature. In short, these positions are conferred by the society creating a superior/inferior relationship between people. Therefore, the relationship is linked with Parsons social action (role). At that point, the generation gap may obtain a good example, as Parsons " ... describes the generation gap typical of contemporary American society as a time in which teenagers' need-dispositions are out of sync with the values of their family as well as wider society. As such, there is a conflict (or gap) between the personality needs of the teenager (e.g. To stay out late, wear "weird" clothes) and the prevailing cultural values and norms (e.g. to respect authority, aspire toward educational and occupational success) as teenagers adopt identities, system of meanings, and social roles that contradict the expectation of parents and teachers." (Appelrouth and Edles, 2008: 355). At that point, there is a discrepancy between pattern variables (Affectivity v. Affective-Neutrality). So, Parsons would say that mobbing is a matter of discrepancy between pattern variables.

It will not be weird to say that generation gap arises from the need to be taken seriously. It is a way of saying that the teenager is an individual with his/her beliefs, opinions and ideas. The prevailing cultural norms and values leaves the teenager in a peculiar disposition where $\mathrm{s} /$ he has to act according to the rules of the others. If we apply the generation gap example in the workplace: In the workplace, the newcomer always arouses suspicion and interest. The new comer experienced or inexperienced has to conform the rules and the norms of the workplace and prove that $\mathrm{s} /$ he is apt for the job. If the newcomer is young or somewhat out of the expectations (positive or negative) s/he has to be subdued to the existing system. So, the target (the so - called victim) calls this process as harassment, bullying, abuse etc. According to Parsons' sociology, that can be called as an complimentary piece of the social system because "there are such close relations between the processes of socialization and of social control that we may take certain features of the processes of socialization as a point of reference for developing a framework for the analysis of the processes of control. The preventive or forestalling aspects of social control consist in a sense of processes which teach the actor not to embark on processes of deviance. They consist in his learning how not to rather than how to in the positive sense of socialization. The re-equilibrating aspects on the other hand are a special case of the learning process in that they involve the unlearning of the alienative elements of the motivational structure." (Parsons, 1991: 201). Because, according to Parsons "system equilibrium ensues when the needs of the personality mesh with the resources available in the social system and cultural values and norms." (Appelrouth and Edles, 2008: 354) Hence, Parsons would say what the deviant person calls mobbing is a normalization process of the deviant person into the social system.

Another point is that the mobbing victims' complaint is being isolated. This is another point shown by Parsons to explain what the purpose of isolation mechanism is for, such as "the insulation mechanisms ... may be interpreted as having the function of preventing potentially conflicting elements in the culture and social structure from coming into the kind of contact which would be likely to lead to open conflict or to exacerbate it - conflict is kept relatively latent." (Parsons, 1991: 209) "Thus the problem of "collectivism" vs. "individualism" as an ideological problem concerns the mode of integration of the individual personality system with the collectivity." (Parsons, 1991: 238) Hence, Parsons would say that mobbing is a preventing mechanism of the social system to keep itself away from the deviant person.

\section{CONCLUSION}

This is a fictional task whose subject is to analyze a current psychological subject in a 
structuralist and functionalist sociological approach. But it should be considered that this study does not attempt to negate the concept of mobbing, instead it attempts to show that mobbing studies are rather victim-oriented. Because, most of the mobbing studies rely on victim-oriented data. By the victims, mobbing itself is a term which is exploited and scapegoated. It is evident that mobbing, despite the massive studies and research in the last two decades, is still somewhat a problematic subject because it was studied only by psychological approaches though it is also a sociological phenomenon.

By using a structuralist and functionalist sociological view, in this paper it is Parsons' approach, it is possible to claim that mobbing should not be considered as a common problem as it has been suggested. Because, mobbing can be viewed as the complaints of so-called mobbing victims' experiencing conflict and re-equilibrium process in the social systems theory and the social action theory. In other words, Parsons would say,

- mobbing is related with the compatibility and determinity of the social system (in this case it is the workplace),

- mobbing is a matter of discrepancy between the pattern variables,

- what the deviant person calls mobbing is a normalization process of the deviant person into the social system,

- mobbing is a preventing mechanism of the social system to keep itself away from the deviant person.

In this study, Parsons' methodology is chosen because it is a an approach that can negate all or most of the claims of mobbing. Mobbing is a popular and current subject but it should be reconsidered what claims are mobbing and what claims are not. Therefore; the aim of this study is to show that mobbing research data and analysis should not only be victim oriented but also they should be bully-oriented. By doing so, it will be found out that mobbing is the result of a group of persons' interactive behaviour which should also be the subject of sociological approach.

\section{REFERENCES}

Appelrouth, Scott ; Edles, Laura Desfor, Classical and Contemporary Sociological Theory, Pine Forge Press, California, 2008.

Blase, Joseph; Blase, Jo; The Dark Side of Leadership: Teacher Perspectives of Principal Mistreatment, Educational Administration Quarterly, Vol. 38, No. 5, December 2002, pp. 671-727.

De Pedro, Mariano Mesaguer; Sanchez, Maria Isabel Soler; Navarro, Maria Concepcion Saez, Izquierdo, Mariano Garcia; Workplace Mobbing and Effects on Workers' Health, The Spanish Journal of Psychology, Vol. 11, No. 1, 2008, pp. 219-227.

Di Pasquale, Verena; Study Examines "Mobbing" at the Workplace, (http:/ /www.eurofound.europa.eu/eir o/2002/08/feature/de0208203f.htm), (10.06.2009).

Edgar, Andrew; "Functionalism", Cultural Theory: The Key Concepts, (Ed.: Andrew Edgar ve Peter Sedgwick), Routledge, Oxon, 2006.

Einarsen, Stale; Hoel, Helge; Zapf, Dieter; Cooper, Cary; The concept of bullying at work: The European Tradition, Bullying and Emotional Abuse in the Workplace International Perspectives in Research and Practice, Taylor \& Francis, London, 2003, pp. 3 - 30.

Kaymakçı, Hülya Aksakal; Sakarya İmalat Sektörünün Görünmeyen Yüzü: Mobbing, 1. Ulusal Çalışma İlişkileri Kongresi, Bildiriler Kitabi, Sakarya Yayıncılık, Adapazarı, 2008, pp. 593 618.

Leyman, Heinz; Mobbing and Psychological Terror at Workplaces, Violence and Victims, Vol. 5, No. 2, 1990, pp. 119 - 126. 
Ok, Ülgen Zeki; İşyerinde Baskı, Taciz ve Yildirma (Mobbing), hhtp: / / www.mobbingturkiye.net, (15.06.2009).

OPSEU; Bullying and Mobbing in the Workplace, Research Paper, June 22, 2007.

Parsons, Talcott; The Social System: With a New Preface by Bryne S. Turner, Routlegde, London, 1991.

Paksoy, Nurettin; İşyerinde Psikolojik Taciz - Yildirma (Mobbing), M.A. Project, Kahramanmaraş Sütçü İmam Üniversitesi, Sosyal Bilimler Enstitüsü, İşletme $\mathrm{ABD}, 2007$.

Pattern Variables, (http://www.sociology.org.uk/pathway1.htm?p1pmp5a. htm), (15.06.2009).

Palaz, Serap; Özkan, Sultan; Sarı, Necla; Göze, Fehim; Şahin, Nurdan; Akkurt, Ömrüye; İş Yerinde Psikolojik Taciz (Mobbing) Davranışları Üzerinde Bir Araştırma; Bandırma Örneği, The Journal of Industrial Relations and Human Resources, Vol: 10, No: 4, September 2008, pp. 41-58.

Rayner, Charlotte; Hoel, Helge; Cooper, Cary L.; Workplace Bullying: What we know, who is to blame, and what can we do?, Taylor \& Francis, London, 2002.

Shallcross, Linda; Sheehan, Michael; Ramsay, Sherly; Workplace Mobbing: Experiences in the Public Sector, International Journal of Organisational Behaviour, Vol. 13, No. 2, 2008, pp. 56 70 .

Slattery, Martin; Sosyoloji'de Temel Fikirler, (Çeviren: Cevdet Özdemir), (Editör: Ümit Tatlıcan; Gülhan Demiriz), Sentez Yayıncilık, Bursa, 2007.

Smith, Philip; Kültürel Kuram, (Çeviren: Selime Güzelsarı; İbrahim Gündoğdu), Babil Yayınları, İstanbul, 2005.
Turner, Bryne S.; Classical Sociology, Sage Publications, London, 1999.

Yücetürk, E. Elif ; Öke, M. Kemal; Mobbing and bullying: legal aspects related to workplace bullying in Turkey, SouthEast Eurpe Review, 2005/2, pp. 61-70. 